\title{
Influence of Spacing, Fertility and Hybrids on Productivity and Profitability of Sweet Corn
}

\author{
Hargilas* \\ Agricultural Research Station (MPUAT), Borwat farm, Banswara-327001, Rajasthan, India \\ *Corresponding author
}

\section{A B S T R A C T}

\begin{tabular}{l} 
K e y w o r d s \\
$\begin{array}{l}\text { Sweet corn, } \\
\text { spacing, fertility, } \\
\text { green cobs \& fodder } \\
\text { yield, total soluble } \\
\text { solids, B:C ratio }\end{array}$ \\
Article Info \\
$\begin{array}{l}\text { Accepted: } \\
\text { 12 February } 2020 \\
\text { Available Online: } \\
\text { 10 March } 2020\end{array}$ \\
\hline
\end{tabular}

A field experiment was conducted at Agricultural Research Station (MPUAT), Borwat farm, Banswara (Rajasthan) during the rainy season of 2018 with objective to evaluate the performance of genotypes under varying plant spacing and fertility levels. The treatment consisted with two spacing viz $60 \times 30 \mathrm{~cm}(55,555$ plants/ha) and 60x 25cm $(66,666$ plants/ha, two fertility level and four sweet corn varieties viz. ASKH-1, Madhuri, Priya and Win-orange. The experiment was Layout in split plot desing with three replicatin. The results revealed that plant growth, green cob yield and economy of sweet corn varying significantly with plant spacing, fertility levels and genotypes. The closer plant spacing of $60 \times 25 \mathrm{~cm}$ was significantly increased plant population, green cobs, net return and $\mathrm{B}: \mathrm{C}$ ratio in tune of $17.24,29.19,33.03$ and $44.62 \%$ higher over wider spacing of $60 \times 30 \mathrm{~cm}$, respectively. Plant height, green fodder yield and net return recorded higher with higher nutrient levels compared lower nutrient level. Among genotypes, Madhuri observed tallest $(227 \mathrm{~cm})$ that found statically at par with priya and Win-orange and significantly $2.11 \%$ superior over ASKH-1. The maximum green cob yield (11.04t/ha), green fodder yield (16.98t/ha), net return (Rs. 75548/ha) and B:C ratio (2.17) obtained with ASKH 1 which green cobs yield was significantly $13.38,31.58$ and $57.77 \%$ higher than mathuri, priya and Win-orange, respectively. The significant effect of plant spacing, nutrient levels and genotypes recorded in term of net return obtained from green cob yield and green fodder yield. The effect of nutrient levels reported non-significant in $\mathrm{B}: \mathrm{C}$ ratio. The closer spacing $(60 \times 25 \mathrm{~cm})$ gave more benefit than wider spacing. ASKH 1 gave higher $\mathrm{B}$ : $\mathrm{C}$ ratio than other varieties.

\section{Introduction}

Sweet corn (Zea mays L. var.saccharata) is a mutant type of corn, with one or more recessive alleles in homozygous condition, which enables the endosperm to accumulate twice the sugar content as that of the seed corn (Creech, 1965). The cob of sweet corn is picked at immature stage (milking stage) of kernel and it prepared and eaten as a vegetable, rather than grain. Sweet corn is growing for fresh green cobs for human consumption and used as raw processed material for the food industry throughout the world. It is an important source of dietary fiber, minerals and certain vitamins. Its taste and nutritional value have made it a valued crop in all countries and the scope of corn 
production is constantly increasing (Olabode and Sangodele, 2015). Sweet corn is emerged as an important cash crop in India because of its shorter growing period and year round demand. It is amenable to processing and preservation and yields green fodder as well. At present, only a limited choice of high yielding sweet corn hybrids is available to the farmers.

Therefore, it offers intensive rotation cultivation in a system for promoting economic and poverty alleviation in periurban area of the country. Among the different agronomic practices, nutrient management, plant density and hybrids are most important factor for determining yield and other agronomic attributes of the crop. The nutrient requirement is very high and the importance of nutrient $(\mathrm{N}, \mathrm{P}$ and $\mathrm{K})$ in maize becomes even more relevant when it is grown as sweet corn because of its high density and very short duration. Hybrids tested for sweet corn to produce more number of green cobs and sugar content as well as green fodder in short with response to nutrient and density. Keeping all these views, the present experiment was conducted to evaluate the yield potential of new hybrids at the economic fertilizer dose and optimum plant spacing under humid southern zone of Rajasthan.

\section{Materials and Methods}

A field experiment was conducted during the rainy season of 2014 at Agricultural Research Station (MPUAT), Borwat farm, Banswara (Rajasthan) located at $23^{\circ} 33^{\prime} \mathrm{N}$ latitude, $74^{\circ} 27^{\prime}$ E longitude and altitude of $220 \mathrm{~m}$ above sea level. The experiment was laid out in split-split plot design with two plant spacing of $60 \times 30 \mathrm{~cm}(55,555$ plants/ha $)$ and $60 \times 25 \mathrm{~cm}(66,666$ plants $/$ ha $)$ in the main plots and two fertilizer doses of $120: 60: 40 \mathrm{~kg}$ and 180:80:60 kg NPK/ha in sub-plots, while four hybrids of ASKH 1, Madhuri, Priya and
Win-orange in sub-sub plots with three replications. The soil of experimental field was clay loam in texture with a $\mathrm{pH}$ value of 8.2 , having $0.54 \%$ organic carbon, $220 \mathrm{~kg} / \mathrm{ha}$ available nitrogen, $22 \mathrm{~kg} / \mathrm{ha}$ available phosphorus and $356 \mathrm{~kg} / \mathrm{ha}$ potassium. The entire dose of phosphorus and potash and 1/3 dose of nitrogen was applied as basal dose in furrow through the tractor drawn fertilizer drill.

The remaining dose of nitrogen applied equally in two splits at knee-high stage and tassel initiation. Ten plants tagged randomly from each plot for recording of growth and yield attributes. The green cobs picked at 15 days after silking when kernels were in milking stage.

Physical parameters of sweet corn like cob weight and TSS value recorded every time of picking whereas, growth parameters like crop growth rate (CGR) was calculated by using standard formula given by Gomez and Gomez (1984).Plant height $(\mathrm{cm})$ recorded at final harvesting of green cob. The crop was harvested after final picking of green cob for green fodder and recorded the green fodder yield. Net returns and BC ratio calculated on basis of prevailing market prices of inputs and produce. Data of each character collected were statistically analyzed using standard procedure of variance analysis.

\section{Results and Discussion}

\section{Growth and yield attributes}

At harvest, plant height was recorded at par with both plant densities whereas; fertility levels have significant effect on plant growth. Maximum plant height $(226 \mathrm{~cm})$ recorded with 180:80:60kg NPK/ha which was $2.73 \%$ significantly higher over lower fertility level of 120:60:40kg NPK/ha. Among verities, Mathuri attained highest plant height $(227 \mathrm{~cm})$ 
which was recorded statistically at par with Win-orange and ASKHI' and significantly superior over Priya. Days of 50\% silking stage was found at par with densities, fertility levels and varieties that proved the days of silking of varieties is not affected with densities and fertility levels. crop growth rate (CGR) and relative growth rate (RGR) were significantly varying from 50 days after sowing to harvest with plant densities, fertility levels and varieties (Table 1).

Cobs/plant were significantly decreased with increased plant density. The maximum no of cobs/ plant (2.27) recorded with 55.55 thousands/ha which was significantly higher than 66.66 thousand plants/ha. Cobs/plant was not significantly affected with fertility levels.

However, cobs/plant was varying with varieties. The maximum cobs/plant recorded in Priya, which was statistically at par with ASKH 1 and Mathuri and significantly superior with Win-orange. The number of kernels/cob was not significantly affected with plant densities.

However, number of kernels/cob increased with increased fertility level. Among the verities, maximum kernels/cob (474) recorded in ASKH 1, which found significantly superior over rest of varieties. Decreasing number of cobs/plant and kernels/cob with increasing plant population that might be due to increased competition and created a stress environmental for plant growth which resulted in more barren plant and less seed formation in cob.

The higher availability of nutrients seems to have promoted development of morphological structure by virtue of multiplication of cell division, which is well reflected through increased plant height, crop growth rate, relative growth rate and number of kernels/cob.
The variation in plant growth and yield attributes observed among the hybrids was mainly due to varietal characters. These finding were reported by Hargilas (2015), Hargilas (2017) and Sahoo (2011).

\section{Yield}

The green cob yield was significantly increasing with increasing plant densities. The maximum green yield (10.19t/ha) was obtained with higher plant density (66666 plants/ha) which was $29.15 \%$ significantly superior over lower plant density (55555 plants/ha).

However, green cob yield not significantly affected by fertility levels. Among, the varieties, ASKH 1 produced maximum green cob yield (11.04t/ha) which was found significantly $13.35,16.03$ and $20.03 \%$ higher over Mathuri, Priya and Win-orange, respectively.

The data showed that green cob yield increased with increased plant density and fertility levels. This may be attributed to more numbers of cobs resulted higher plant population with better availability of nutrients at higher fertility level (Hargilas 2015). The green cob yield varied with varieties might be due to yield potential of varieties (Hargilas, 2017). Green fodder yield recorded statistically at par with plant densities and fertility levels.

However, green fodder yield was varying with varieties. The maximum fodder yield (17.30 t/ha) recorded with Mathuri which was $1.88,16.34$ and $51.22 \%$ significantly superior over ASKH 1, Priya and Win-orange, respectively. Fodder yield variation within varieties might be fodder yield potential of varieties. These results were in agreement with the findings of Sahoo and Mahapatra (2007) and Hargilas (2015). 


\section{Economics}

The data for net return and $\mathrm{B}: \mathrm{C}$ ratio presented in table 2 revealed that the net return from green cob at harvesting was significantly influenced by plant density. The maximum net return (Rs 66573/ha) recorded at higher plant density (66666 plants/ha) which was $49.41 \%$ significantly superior over lower plant density (55555 plants/ha). The higher net return obtained with higher plant density might be due to higher green cob yield in the high plant density.Net return increased with fertility levels but it was recorded statistically at par with both fertility levels.

Table.1 Effect of plant spacing, fertility levels on growth and yield attributes of sweet corn varieties

\begin{tabular}{|c|c|c|c|c|c|c|}
\hline \multirow[t]{2}{*}{ Treatments } & \multirow[t]{2}{*}{$\begin{array}{c}\text { Plant height at } \\
\text { harvest }(\mathrm{cm})\end{array}$} & \multirow[t]{2}{*}{$\begin{array}{c}\mathbf{5 0 \%} \\
\text { silking }\end{array}$} & \multicolumn{2}{|c|}{$\begin{array}{l}50 \text { DAS to } \\
\text { harvest }\end{array}$} & \multicolumn{2}{|c|}{ Yield attributes } \\
\hline & & & CGR & RGR & Cobs/plant & Kernels/cob \\
\hline \multicolumn{7}{|c|}{ Plant density ('000/ha) } \\
\hline 55.55 & 223 & 48.8 & 2.21 & 0.238 & 2.27 & 416 \\
\hline 66.66 & 222 & 49.4 & 2.35 & 0.252 & 1.12 & 409 \\
\hline $\mathrm{CD}(\mathrm{P}=\mathbf{0 . 0 5})$ & NS & NS & 0.08 & 0.010 & 0.11 & 22 \\
\hline \multicolumn{7}{|c|}{ Fertility level ( $\mathrm{N}: \mathrm{P}_{2} \mathrm{O}_{5}: \mathrm{K}_{2} \mathrm{O}$ kg/ha) } \\
\hline 120:60:40 & 220 & 49.4 & 2.25 & 0.240 & 1.13 & 396 \\
\hline 150:80:60 & 226 & 48.9 & 2.31 & 0.246 & 1.13 & 428 \\
\hline $\mathrm{CD}(\mathrm{P}=\mathbf{0 . 0 5})$ & 4.9 & NS & 0.03 & 0.005 & NS & 18 \\
\hline \multicolumn{7}{|l|}{ Varieties } \\
\hline ASKH 1 & 223 & 49.4 & 2.52 & 0.270 & 1.16 & 474 \\
\hline Mathuri & 227 & 48.8 & 3.14 & 0.334 & 1.19 & 405 \\
\hline Priya & 217 & 49.2 & 2.85 & 0.305 & 1.22 & 387 \\
\hline Win-orange & 224 & 49.1 & 2.28 & 0.243 & 0.94 & 383 \\
\hline $\mathrm{CD}(\mathrm{P}=0.05)$ & 6.6 & NS & 0.08 & 0.008 & 0.16 & 31 \\
\hline
\end{tabular}

It might be due to increase the cost of cultivation with higher fertility level. Among the varieties, maximum net return (Rs 75548/) obtained from green cob yield of ASKH 1 which was recorded significantly superior over Mathuri, Priya and Win-orange by 20.84 , 54.03 and $115.08 \%$ respectively.

This result might be due to significant variation in green cob yield of varieties. The $\mathrm{B}: \mathrm{C}$ ratio was significantly varied with plant densities. The maximum B:C ratio (1.88) was recorded with higher plant density which was
$44.61 \%$ significantly superior over lower plant density. However, B:C ratio was not influenced with fertility levels. It might be due to increase the cost of inputs.

Among the varieties, the maximum $\mathrm{B}: \mathrm{C}$ ratio (2.17) was recorded in ASKH 1 which was $21.23,55.00$ and $114.85 \%$ higher over Mathuri, Priya and Win-orange, respectively. This might be on account of green cobs yield of varieties. These similar finding were observed by Sahoo and Mahapatra (2007) and Hargilas (2015). 


\section{Quality parameter}

Quality parameter as total soluble solids (TSS) content is showed in table 2. The total soluble sugar content was no significantly affected to plant densities and fertility levels, but it was significantly varied with varieties. Highest total soluble solids (17.2) content was recorded under grains of ASKH 1, which was
5.52, 13.91 and $20.28 \%$ significantly higher over Mathuri, Priya and Win-orange, respectively. There present investigation all varieties were grown under identical conditions, however, marked variation in quality parameter could be due to difference of their genetic make-up. The similar findings were recorded by Shobha, et al., (2010).

Table.2 Effect of plant spacing, fertility levels on growth and yield, economic and total soluble solids of sweet corn varieties

\begin{tabular}{|c|c|c|c|c|c|}
\hline \multirow[t]{2}{*}{ Treatments } & \multicolumn{2}{|c|}{ Yield (t/ha) } & \multicolumn{2}{|c|}{ Economics } & \multirow[t]{2}{*}{ TSS } \\
\hline & Green cob & Green fodder & Net return (Rs/ha) & $\mathrm{B}: \mathrm{C}$ ratio & \\
\hline \multicolumn{6}{|c|}{ Plant density (000/ha) } \\
\hline 55.55 & 7.89 & 14.69 & 44546 & 1.30 & 15.8 \\
\hline 66.66 & 10.19 & 15.60 & 66573 & 1.88 & 15.7 \\
\hline $\mathrm{CD}(\mathbf{P}=0.05)$ & 0.55 & NS & 5539 & 0.2 & NS \\
\hline \multicolumn{6}{|c|}{ Fertility level $\left(\mathrm{N}: \mathrm{P}_{2} \mathrm{O}_{5}: \mathrm{K}_{2} \mathrm{O} \mathrm{kg} / \mathrm{ha}\right)$} \\
\hline 120:60:40 & 8.88 & 14.94 & 55180 & 1.64 & 15.7 \\
\hline $150: 80: 60$ & 9.21 & 15.35 & 55939 & 1.54 & 15.8 \\
\hline $\mathrm{CD}(\mathrm{P}=0.05)$ & NS & NS & NS & NS & 0.1 \\
\hline \multicolumn{6}{|l|}{ Varieties } \\
\hline ASKH 1 & 11.04 & 16.98 & 75548 & 2.17 & 17.2 \\
\hline Mathuri & 9.74 & 17.30 & 62518 & 1.79 & 16.3 \\
\hline Priya & 8.39 & 14.87 & 49047 & 1.40 & 15.1 \\
\hline Win-Orange & 6.99 & 11.44 & 35125 & 1.01 & 14.3 \\
\hline $\mathrm{CD}(\mathrm{P}=0.05)$ & 1.05 & 0.75 & 10520 & 0.3 & 0.1 \\
\hline
\end{tabular}

From the experimental results, it can be concluded that, cultivation of maize variety AKSH 1 with planting density of 66,000 plants/ha and fertility level of 180:80:60 N, $\mathrm{P}_{2} \mathrm{O}_{5}$ and $\mathrm{K}_{2} \mathrm{O} \mathrm{kg} / \mathrm{ha}$ is a recommendable option for achieving higher yield and economic benefit during kharif season under sub humid condition of Southern Rajasthan.

\section{References}

Creech, R.G. 1965.Genetic control of Hargilas, Singh, A.K., Jat, S.L., Rokadia, P.K. carbohydrates synthesis in maize endosperm. Genetics, 52: 1175-1186.

Gomez, K.A. and Gomez, A.A. 1984. Statistical procedures for agricultural research. John Wiley \& Sons.

Hargilas, 2015. Evaluation of baby corn hybrids productivity and profitability under different fertilizer doses and spacing. International Journal of Bioresource and Stress Management 2015, 6(4):503-508. 
and Kumar, Arvid, 2017. Response of maize (Zea mays) hybrids to nutrient management practices for enhancing productivity and profitability under subhumid condition of Southern Rajasthan. Indian Journal of Agronomy 62 (3): 326-331.

Olabode, O.S. and Sangodele, A.O. (2015). Effect of weed control methods on the performance of sweet corn (Zea mays var. saccharata) in Ogbomoso, South West Nigeria. Journal of Global Biosciences, 4(1):1145-1150.

Sahoo, S.C. and Mahapatra, P.K. (2004). Response of sweet corn (Zea mays) to nitrogen levels and plant population. Indian Journal of Agricultural Science, 74(6):337-338.

Sahoo, S.C. and Mahapatra, P.K. (2007). Yield and economics of sweet corn (Zea mays) as affected by plant population and fertility levels. Indian Journal of Agronomy, 52(3): 239-242.

Shobha, D, Sheerramasetty, T.A., Puttaramanaik and Pandurangegowda, K.T.(2010). Evaluation of maize genotypes for physical and chemical composition at silky and hard stage. Karnataka Journal of Agricultural Science, 23(2): 311-314.

\section{How to cite this article:}

Hargilas. 2020. Influence of Spacing, Fertility and Hybrids on Productivity and Profitability of Sweet Corn. Int.J.Curr.Microbiol.App.Sci. 9(03): 1772-1777.

doi: https://doi.org/10.20546/ijcmas.2020.903.205 